\title{
Landlocked Fall Chinook Salmon Sperm Motility after Short Term Milt Storage
}

\author{
Sara E. Reese, Anthony J. Long, Hilary A. Meyer, Michael E. Barnes* \\ South Dakota Department of Game, Fish and Parks, Missouri River Fisheries Center, \\ 523 East Capitol, Pierre, South Dakota 57501-3182, USA \\ *South Dakota Department of Game, Fish and Parks, McNenny State Fish Hatchery, \\ 19619 Trout Loop, Spearfish, South Dakota 57783-8905, USA \\ mike.barnes@state.sd.us
}

\begin{abstract}
During salmonid spawning, milt is frequently stored on ice prior to use. This study evaluated landlocked fall Chinook salmon (Oncorhynchus tshawytscha) sperm motility during the first two hours of milt storage. Motility duration was recorded immediately after stripping and every 20 minutes for two hours thereafter from the milt of eight males on two spawning days. Sperm remained motile for the entire two hour period on both days, although the duration of motility was significantly greater on the first spawning day in comparison to the second day one week later. On the first spawning day, sperm motility duration was over 40 seconds throughout the entire two hour period, and did not significantly differ among sampling times. On the second spawning day, motility duration significantly declined after 80 minutes of milt storage on ice to a mean of approximately 30 seconds, although this decline was likely not severe enough to impact salmon sperm fertilizing capabilities. These results indicate that milt can be successfully stored on ice for up to two hours poststripping with only minimal impacts on sperm motility.
\end{abstract}

Keywords: Chinook salmon; Milt; Sperm; Motility; Oncorhynchus tshawytscha; Lake Oahe.

\section{INTRODUCTION}

Adequate sperm motility is essential for successful fertilization in fishes during artificial propagation [1-3]. Sperm from most fish species is inactive in milt, and only becomes motile upon contact with activating solutions such as water or ovarian fluid [1,4]. Once activated, the sperm are then able to pass through the micropyle and fertilize the eggs [5]. Sperm from salmonids exhibits particularly short durations of motility, with maximum motility of only 15 to 40 seconds, and immotility after several minutes [4,6,7]. Milt is frequently stored prior to spawning, with the resulting sperm motility influenced by the duration of milt storage and storage conditions, such as temperature, oxygen content, anesthesia, ion concentrations, and $\mathrm{pH}[3,8-11]$.

The population of landlocked fall Chinook salmon (Oncorhynchus tshawytscha) in Lake Oahe, South Dakotais entirely dependent on hatchery production from feral fish [12], with the resulting egg survival typically very low $[13,14]$. Standard Lake Oahe Chinook salmon spawning procedures involve placing the milt on ice immediately after stripping, with subsequent use up to an hour later. The possible effects of milt storage on sperm motility in landlocked fall Chinook salmon has never been evaluated. This study was initiated to address this lack of knowledge, in light of the historically low reproductive success during hatchery incubation of this specific population. Thus, the objective of this study was to determine the motility at various time intervals of landlocked fall Chinook salmon sperm after milt storage on ice.

\section{MATERIALS AND MethodS}

\section{Milt Collection}

Milt and data collection occurred during spawning on October 26 and November 3, 2016 at Whitlocks Spawning Station near Gettysburg, South Dakota, USA. On each of the spawning dates, four mature males were randomly selected from a pool of approximately 20 males which had undergone carbon dioxide anesthesia. Each male was manually stripped via abdominal massage [4], with approximately $40 \mathrm{~mL}$ of milt collected in a 50mL plastic centrifuge tube (Fisher Scientific, Chicago, Illinois, USA). Milt from each male was maintained discretely throughout the experiment. Each tube was placed into 
a rack, with the entire rack placed into a plastic pan containing an ice-water bath rising to approximately $50 \%$ of the tube height. The timing of milt collection from individual males was staggered to record duration of motility immediately post-stripping (time-0).

\section{Sperm Motility}

Sperm motility was defined as progressive forward movement, while immotility was defined as movement within place, circular vibration, or no sperm movement at all. Duration of motility was examined over two hours at 20 minute intervals, beginning immediately after stripping (time-0). The two hour time limit was used because spawning operations, and milt storage, typically only occur for one hour, and never exceed two hours. To assess motility, milt was removed from each tube using a 3$\mathrm{mm}$ sterile syringe with a 22 -gauge, $3 / 4$-inch sterile needle and placed on a microscope slide. Using a plastic $5 \mathrm{~mL}$ pipette, two drops of lake water were placed on the slide to activate the sperm. Immediately after activation, a cover slip was placed on the slide, and the slide was viewed under a Motic BA310LED compound microscope (Motic, Hong Kong, China) at 40x magnification. The presence or absence of motility was recorded, and if motility was observed, the number of seconds sperm remained motile was recorded. Both temperature of the ice bath and temperature of the milt were recorded at each sampling interval. The lake water used for activation was between 12.5 and $13^{\circ} \mathrm{C}$ on both spawn days.

\section{Statistical analysis}

One-way repeated measures analysis of variance (ANOVA) was used to test for significant differences in motility duration between the two spawn days $(\alpha=0.05)$.A significant difference in duration of motility existed between groups ( $p<0.001)$; therefore, each group was analyzed separately. Two-way repeated measures ANOVA was used to test for the effects of milt temperature, time after stripping, and the interaction between milt temperature $\times$ time after stripping on duration of motility. Where appropriate, differences between groups were evaluated with a post-hoc, paired t-test with a Holm correction. All analyses were performed using R version 3.1.2 [15].

\section{RESULTS AND DISCUSSION}

In all samples, sperm exhibited motility for the entire two hour period. No significant differences in sperm motility duration over time were observed on the first spawn day, with mean sperm motility duration ranging from 76 seconds ( \pm 10 seconds; SE) at 20 minutes after stripping to 43 seconds $( \pm 5$ seconds) at 120 minutes (Figure 1).Mean sperm motility duration on the second spawning day ranged from 51 seconds ( \pm 4 seconds) at time- 0 to 29 seconds ( \pm 2 seconds) at both 100 minutes and 120 minutes after stripping, and the duration of sperm motility at 80,100, and 120 minutes post-stripping was significantly lower compared to sperm motility at time- 0 and 20 minutes after stripping $(F=7.1$; $\mathrm{df}=6 ; p=0.003)$. Duration of sperm motility differed significantly between the first and second spawn days $(F=60.5 ; \mathrm{df}=1 ; p<0.0001)$.

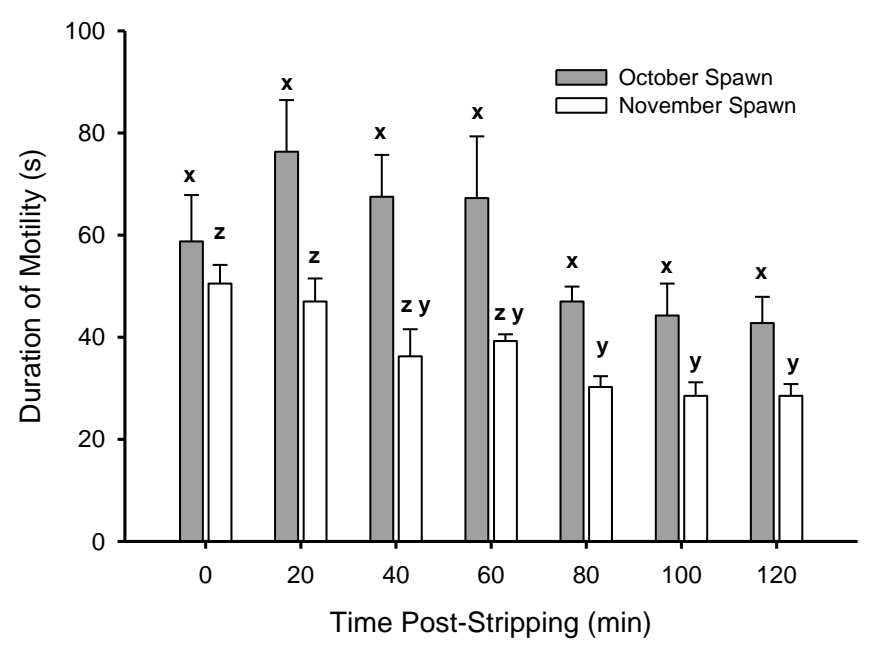

Figure 1. Duration of landlocked Chinook salmon sperm motility ( $s$ ) at time post stripping (minutes) on either October 26 or November 3, 2016. Values within the same spawning day that share a common letter are not significantly different $(p<0.05)$. Error bars represent 1 standard error. 
Mean milt temperature was similar between spawn days (Figure 2). On the first spawn day, mean milt temperature was $13.9^{\circ} \mathrm{C}$ at time- 0 and $5.3^{\circ} \mathrm{C}$ at 100 minutes. On the second spawn day, mean milt temperature decreased from $11.8^{\circ} \mathrm{C}$ at time- 0 to $5.3^{\circ} \mathrm{C}$ at 60 minutes, and increased to $8.8^{\circ} \mathrm{C}$ at 120 minutes (Figure 2).

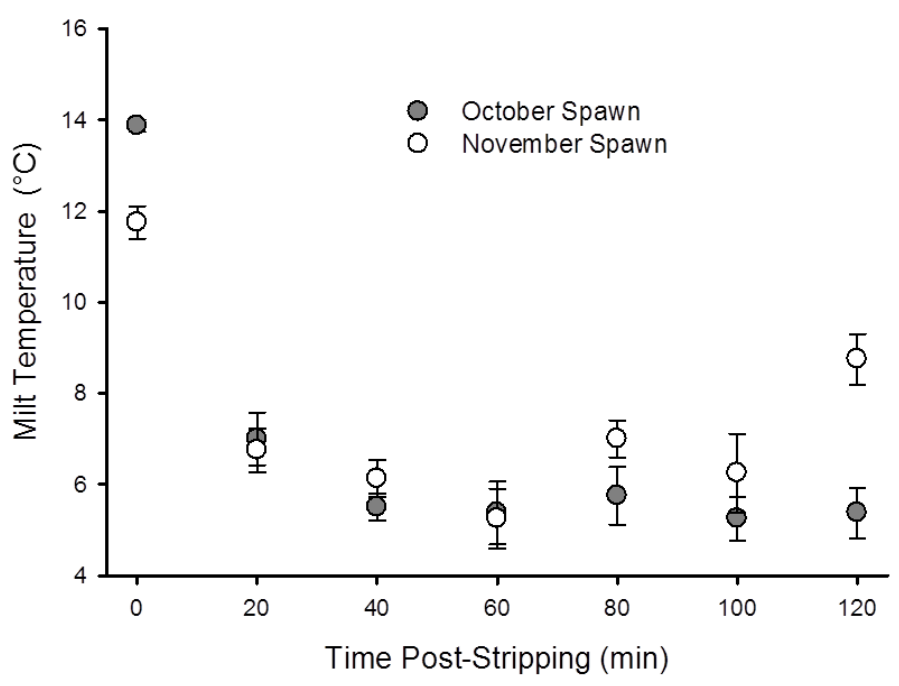

Figure 2. Mean milt temperature $\left({ }^{\circ} \mathrm{C}\right)$ at time post stripping (minutes) of landlocked fall Chinook salmon spawned on October 26th (gray circles) and November 3rd (white circles) 2016. Error bars represent 1 standard error.

This study documents for the first time that landlocked fall Chinook salmon sperm can maintain motility after being stored on ice for at least two hours. These results are similar to that observed in other salmonid species. Atlantic salmon (Salmo salar) sperm held at $4{ }^{\circ} \mathrm{C}$ had no decline in motility up to four hours after stripping [16]. Both sockeye salmon $(O$. nerka) and pink salmon $(O$. gorbuscha $)$ milt refrigerated for several days at temperatures $<3.2^{\circ} \mathrm{C}$ were able to maintain high fertilization rates [17].In contrast, rainbow trout (O. mykiss) sperm held between $13^{\circ} \mathrm{C}$ and $15^{\circ} \mathrm{C}$ was completely immotile after 20 to 30 seconds [6]. This suggests that keeping sperm at a lower temperature for the duration of this study was an important factor in maintaining sperm motility. The decline in the duration of sperm motility after 60 minutes on the second spawning day is similar to results obtained with rainbow trout milt [18]. No decrease in rainbow trout sperm motility was observed for up to 60 minutes after stripping, but significant decreases in motility were observed by 120 minutes poststripping [18].

In addition to storage temperature, oxygen availability is another important factor in maintaining sperm quality during milt storage [1,19-22]. Fish sperm cannot survive in an anoxic environment [20], and several authors have documented the benefits of oxygen availability to stored salmonid sperm $[19,22,23]$. Although not measured, differences in the oxygen content during storage may have played a role in the observed decrease in motility over the two hour period, and could possibly explain the differences observed between the two spawning dates.

Differences in duration of sperm motility between spawn dates could also be associated with differences in male condition. Sperm quality, as defined by characteristics such as motility, flagellal presence, and sperm head shape, has been reported to change as the spawning season progresses $[22,24,25]$. The duration of rainbow trout sperm motility has been observed to significantly peak during the middle of the spawning season, but was comparatively lower at the beginning and end of the spawning season [26]. The first spawning date used in this study was approximately 10 days after the peak of spawning, and the second spawning date was 17 days post-peak [27]. It is possible that the differences in sperm motility duration between the two spawning dates may have been due to differences in male condition.

\section{CONCLUSIONS}

In conclusion, Lake Oahe Chinook salmon sperm remained motile for the entire two hour study. Although the duration of motility significantly declined after 80 minutes on the second spawning date, this decline was likely not severe enough to impact sperm fertilization capabilities. Therefore, 
landlocked fall Chinook salmon sperm can be safely stored on ice for up to two hours prior to use during egg fertilization as part of spawning activities.

\section{ACKNOWLEDGEMENTS}

We thank Robert Hanten, Kyle Potter, and the spawning crew at Whitlock's Spawning Station for their assistance with this study.

\section{REFERENCES}

[1] Rurangwa E., Kime D. E., Ollevier F. and Nash J. P. The measurement of sperm motility and factors affecting sperm quality in cultured fish. Aquaculture. 2004, 234: 1-28.

[2] Bobe J., and Labbé C. Egg and sperm quality in fish. Gen Comp Endocrinol2010, 165: 535-548.

[3] Trigo P., Merino O., Figueroa E., ValdebenitoI., Sánchez R., and Risopatrón J. Effort of shortterm semen storage in salmon (Oncorhynchus mykiss) on sperm functional parameters evaluated by flow cytometry. Andrologia2014, 47: 407-411.

[4] Piper R. G., McElwain I. B., Orme L. E., McCaren J. P., Fowler L. G. and Leonard J. R. Fish hatchery management. US Fish and Wildlife Service. 1982.

[5] Billard R. and, Cosson, M. P. Some problems related to the assessment of sperm motility in freshwater fish. J ExpZool1992, 261: 122-131.

[6] Christen R., Gatti J., and Billard R. Trout sperm motility: The transient movement of trout sperm is related to changes in the concentration of ATP following the activation of the flagellar movement. European J Biochem1987, 166: 667-671.

[7] Fitzpatrick J. L., Henry J. C., Liley N. R., and Devlin R. H. Sperm characteristics and fertilization success of masculinized coho salmon (Oncorhynchus kisutch). Aquaculture 2005, 249: 459-468.

[8] Vladić T., and Järvi T. Sperm motility and fertilization time span in Atlantic salmon and brown trout - the effect of water temperature. J Fish Biol1997, 50: 1088-1093.

[9] Morisawa M., Oda S., Yoshida M., and Takai M. H. Transmembrane signal transduction for the regulation of sperm motility in fishes and ascidians. In: Gagnon C, Ed. The male gamete: From basic knowledge to clinical applications. Cache River Press, 1999, pp. 149-160.

[10] Wagner E., Arndt R. and Hilton B. Physiological stress responses, egg survival and sperm motility for rainbow trout broodstock anesthetized with clove oil, tricainemethanesolfonate or carbon dioxide. Aquaculture 2002, 211: 353-366.

[11] Alavi S. M. H. and Cosson J. Sperm motility in fishes. I. Effects of temperature and pH: a review. Cell BiolInt2005, 29: 101-110.

[12] Lott J., Marrone G. and Stout D. Influence of size-and-date at stocking, imprinting attempts and growth on initial survival, homing ability, maturation patterns and angler harvest of Chinook salmon in Lake Oahe, South Dakota. Progress Report 97-20.South Dakota Department of Game, Fish and Parks.1997.

[13] Barnes M. E., Hanten R. P., Cordes R. J., Sayler W.A. and Carreiro J. Reproductive performance of inland fall chinook salmon. N Am J Aquac 2000, 62: 203-211.

[14] Young K. L., Barnes M. E., and Kientz J. L. Reproductive characteristics of landlocked fall Chinook salmon from Lake Oahe, South Dakota. Prairie Nat, 2016 48:79-86.

[15] R Core Team [homepage on the internet]. Vienna, Austria: RFoundation for Statistical Computing 2014 [cited Dec 12 2016]. Available from http://www.R-project.org/.

[16] Gage M. J. G., Macfarlane C. P., Yeates S., Ward R. G., Searle J. B. and Parker G.A. Spermatozoal traits and sperm competition in Atlantic salmon: relative sperm velocity in the primary determinant of fertilization success. Curr Biol 2004, 14: 44-47.

[17] Withler F. C. and Morley R.B. Effects of chilled storage on viability of stored ova and sperm of sockeye and pink salmon. J Fish Res Board Can 1968, 25: 2695-2699.

[18] Lahnsteiner F.,Weismann T. and Patzner R. A. Aging processes of rainbow trout semen during storage. Progres Fish-Cultur 1997, 59: 272-279.

[19] Stoss J. and Holtz W. Successful storage of chilled rainbow trout (Salmo gairdneri) spermatozoa for up to 34 days. Aquaculture 1983, 31: 269-274. 
[20] Bencic D. C., Krisfalusi M., Cloud J. G. and Ingermann R. L. Short-term storage of salmonid sperm in air versus oxygen. N Am J Aquac2000, 62: 19-25.

[21] Jenkins-Keeran K., Schreuders P., Edwards K. and Woods III L. C. The effects of oxygen on the short-term storage of striped bass semen. N Am J Aquac2001, 63: 238-241.

[22] Bobe J. and Labbé C. Chilled storage of sperm and eggs. In: Cabrita E, Robles V, Herráez P, Ed. Methods in reproductive aquaculture: Marine and freshwater species. CRC Press 2009, pp. 219235.

[23] Kowalski R. K., Cejko B. I., Irnazarow I., Szczepkowski M., Dobosz S. and Glogowski J. Shortterm storage of diluted fish sperm in air versus oxygen. Turk J Fish AquatSci2014, 14: 831-834.

[24] Munkittrick K. R. and Moccia R. D. Seasonal changes in the quality of rainbow trout (Salmo gairdneri) semen: Effect of a delay in stripping on spermatocrit, motility, volume and seminal plasma constituents. Aquaculture 1987, 64: 147-156.

[25] Cabrita E., Robles V. and Herráez P. Chilled storage of sperm and eggs. In: Cabrita E, Robles V, Herráez P, Ed. Methods in reproductive aquaculture: Marine and freshwater species. CRC Press 2009, pp. 93-147.

[26] Büyükhatipoglu S. and Holtz W. Sperm output in rainbow trout (Salmo gairdneri) - Effect of age, timing and frequency of stripping and presence of females. Aquaculture 1984, 37: 63-71.

[27] Hanten R. P. 2010 Whitlocks Bay Salmon Spawning Station Report 11-02. South Dakota Game, Fish and Parks. 2011. 